\title{
Necheminių piktžolių kontrolès būdų efektyvumo palyginimas vasarinių rapsų pasėlyje ekologinės žemdirbystės sąlygomis
}

\section{Rimantas Velička, \\ Rita Mockevičienė, \\ Aušra Marcinkevičienė,}

Rita Pupalienè,

Lina Marija Butkevičienė,

Zita Kriaučiūnienė,

Robertas Kosteckas,

Sigitas Čekanauskas

Aleksandro Stulginskio universitetas,

Studenty g. 11,

LT-53361 Akademija, Kauno r.

El.paštas ausra.marcinkeviciene@asu.lt
Rapsų auginimo ekologinèje žemdirbystes sistemoje tyrimų pasaulyje atlikta nemažai, tačiau Lietuvos klimatinèmis sąlygomis jų trūksta, ypač taikant pažangias piktžolių kontrolès priemones. Lauko eksperimentas atliktas 2013-2014 m. Aleksandro Stulginskio universiteto Bandymų stotyje. Dirvožemis - giliau glèjiškas išplautžemis (Endohypogleyic Luvisol). Tyrimų tikslas - įvertinti necheminių piktžolių kontrolès būdų efektyvumą vasarinių rapsų pasèlio piktžolètumui bei sèklų derlingumui ekologinès žemdirbystès sąlygomis. Eksperimento variantai: necheminiai piktžolių kontrolès būdai: 1) terminis (drègnuoju vandens garu); 2) mechaninis (tarpueilių purenimas); 3) savireguliacija (stelbimas).

Pavasarị vasarinių rapsų pasèlyje vyravo baltoji balanda, raudonžiedè notrelè ir daržinè žliūgè. Mechaniniam piktžolių naikinimui jautriausia buvo baltoji balanda, o terminiam - raudonžiedè notrelè ir daržinè žliūgè. Piktžoliu daigų skaičius esmingai mažějo taikant termini (nuo 1,5 iki 1,8 karto) bei mechanini (nuo 2,5 iki 6,8 karto) piktžolių kontrolès būdus vasarinių rapsų pasèlyje, palyginti su savireguliacija. Efektyviausias piktžolių kontrolès būdas ekologiškai auginamų rapsų pasèlyje buvo mechaninis (efektyvumas 30,9-75,5\%). Terminio piktžolių kontrolès būdo efektyvumas, palyginti su mechaniniu, buvo mažesnis $(28,4-40,0 \%)$. Prieš nuimant derlių rapsų pasèlyje, kur taikytas mechaninis piktžolių naikinimas, palyginti su savireguliacija, piktžolių skaičius buvo esmingai mažesnis 3,2-4,4 karto, piktžolių sausujjų medžiagų mase - 2,2-3,1 karto. Auginant vasarinius rapsus ekologinès gamybos ūkiuose efektyviau taikyti mechanini piktžolių kontrolès būdą nei terminị, nes vidutinis rapsų sèklų derlingumas gaunamas $15,8 \%$ didesnis. Vasarinių rapsų derlingumas priklausẻ nuo piktžolių daigų skaičiaus prieš panaudojant kontrolès būdus $(r=-0,99, r<0,05)$ ir piktžolių sausụjų medžiagų masès - prieš nuimant derlių $(r=-0,99, r<0,05)$.

Raktažodžiai: Brassica napus L. ssp. oleifera annua Metzg., piktžoliu kontrolès būdai, piktžolès, efektyvumas, sèklų derlingumas, ekologinè žemdirbystè

\section{IVADAS}

Didejjant sveiko, pesticidų likučiais neužteršto maisto poreikiui, aktualus yra rapsų auginimas ekologinès gamybos ūkiuose. Viena iš priežasčių, kodèl ekologinès gamybos ūkiuose rapsų plotai nedideja, yra piktžolių, ligų ir kenkëjų kontrolès problema bei mažas sèklų derlingumas (Valantin-Morison,
Meynard, 2008). Ekologinès gamybos ūkiuose nesant galimybès piktžoles naikinti herbicidais, rapsu konkurencingumui pasèlyje didinti reikia taikyti alternatyvias priemones: sèti platesniais tarpueiliais sudarant galimybę piktžoles juose naikinti žemès dirbimu bei drègnuoju vandens garu; rapsus auginti suformuojant tankesni pasèli, parenkant geriau piktžoles stelbiančias veisles, sejjant optimaliu 
laiku ir kt. E. C. Oerke (2005) konstatavo, kad didžiausi žemės ùkio augalų derliaus nuostoliai buvo dèl piktžolių (34\%), o dèl kenkèjų ir ligų sukèlèju - mažesni (siekè 18 ir $16 \%$ ). Piktžolès yra ir bus didelè problema ekologinèje žemdirbystèje (Lundkvist et al., 2008). Todèl piktžolių kontrolès būdai, kuriais galima sumažinti pasèlio piktžolètumą, yra svarbūs, juos būtina naudoti derinant su tam tikro žemès ūkio augalo auginimo technologijomis.

Mechaninis piktžolių naikinimas tarpueiliuose yra praktikuojamas ekologiniuose ūkiuose ir gali labai sumažinti pasèlių piktžolètumą (Praczyk, 2005). Mechaninio piktžolių kontrolès būdo efektyvumas priklauso nuo jo taikymo laiko ir intensyvumo (Kurstjens, Perdok, 2000; Kurstjens, Kropff, 2001; Melander et al., 2013). Mechaniniam piktžolių naikinimui jautri baltoji balanda (Chenopodium album L.), daržinė žliūgè (Stellaria media (L.) Vill), daržinè našlaitė (Viola arvensis Murray) (Auškalnienė, Lukošiūnas, 2003). Mechaniniu būdu efektyviausia piktžoles naikinti iki jų 4 tikrųjų lapelių tarpsnio (Lieven et al., 2008).

Terminis piktžolių naikinimas - ekologiškas piktžolių kontrolès būdas. Terminiam piktžolių naikinimui naudojant drégnajji vandens garą, augalo aplinkoje sukuriamos ypatingos temperatūros sąlygos $-99^{\circ} \mathrm{C}$. Šilumos perdavimo procesas labai intensyvus, vandens garo kondensacija vyksta augalu ir dirvos paviršiuose (Kerpauskas ir kt., 2010; Sirvydas, Kerpauskas, 2012). Piktžolių naikinimas drègnuoju vandens garu pasaulyje nèra paplitęs ir palyginti mažai tirtas (Collins, 2000). Platesni piktžolių terminès kontrolès drégnuoju vandens garu tyrimai atlikti tik Lietuvos mokslininkų (Kerpauskas, 2003; Vasinauskienė, 2004; Virbickaitė ir kt., 2006; Kerpauskas ir kt., 2006; Kerpauskas ir kt., 2010; Staniuliene, 2010; Sirvydas, Kerpauskas, 2012). Terminio piktžolių kontrolès būdo efektyvumas priklauso nuo piktžolių rūšinès sudèties. R. Vasinauskienès (2003) ir R. Staniulienès (2010) gauti tyrimų duomenys rodo, kad miglinių šeimos piktžolès jautriausios aukštatemperatūrinei aplinkai vieno-dviejų lapelių augimo tarpsniu. Kitais augimo tarpsniais reikalinga prailginta aukštatemperatūrinès aplinkos terminio poveikio trukmè. Skrotelinès piktžolès (trikertè žvaginè (Capsella bursa-pastoris L. Medik)) jautriausios aukštos temperatūros aplinkai iki 10 lapelių augimo tarpsnio. Kai lapelių skaičius pasiekia 11-15, terminiam sunaikinimui daro ittaką lapų posvyrio kampas (Staniuliene, 2010). P. Kerpauskas ir kt. (2006) nustatè, kad taikant terminę piktžolių kontrolę drègnuoju vandens garu piktžolių sausujų medžiagų masè sumažèja 44,0 \%.

Vienas iš pigiausių ir ekologišku požiūriu naudingiausių piktžolių kontrolès būdų rapsų pasèlyje - augalų konkurencinių savybių panaudojimas piktžolėms stelbti (Zakharenko, 2000). Piktžolès - natūralūs dirbamų žemių augalų bendrijų (agrofitocenozių) komponentai (Debeljak et al., 2008). Piktžolès rapsus ypač stelbia vegetacijos pradžioje ir pasèliui išretejjus (Velička, Trečiokas, 2002). Žemès ūkio augalų pajègumas stelbti piktžoles yra nevienodas, jis priklauso nuo augalo biologinių savybių (Börner, 1995), veislès (Hamzei et al., 2007), sejjos laiko ir suformuoto pasèlio tankumo (Bullied et al., 2006), priešsèlio (Valantin-Morison, Meynard, 2008), meteorologinių sąlygų, piktžoliu plitimo intensyvumo ir dominuojančių piktžolių (Seem et al., 2003). Kai kurie autoriai teigia, kad geromis sąlygomis (sukultūrintame optimaliai patręštame dirvožemyje, kur išnaikintos daugiametès ir trumpaamžès piktžolès bei piktžolių sèklos) augantys žemès ūkio augalai, suformavus pakankamai tankų pasėli, tinkamai parinkus veisles, patys sugeba stelbti piktžoles (Lazauskas, 1990; Pilipavičius, 2006). W. J. Bullied ir kt. (2006) duomenimis, kuo anksčiau pasèti rapsai ir suformuotas tankesnis pasèlis, tuo augalu konkurencinis pajëgumas buvo didesnis.

Lietuvos klimatinėmis sąlygomis vasarinių rapsų auginimo ekologinejje žemdirbystès sistemoje tyrimų atlikta mažai, ypač taikant ekologines pažangias piktžolių kontrolès priemones.

Tyrimų tikslas - nustatyti necheminių piktžolių kontrolès būdų efektyvumą vasarinių rapsų pasèlio piktžolètumui ir sèklų derlingumui ekologinès žemdirbystès sąlygomis.

\section{TYRIMŲ METODAI IR SĄLYGOS}

Lauko eksperimentas vykdytas 2013-2014 m. Aleksandro Stulginskio universiteto (ASU) Bandymų stotyje. Dirvožemis - karbonatingas giliau glejjiškas išplautžemis (IDg4-k) (Calc(ar)i-Endohypogleyic Luvisol) (LVg-n-w-cc). Eksperimento dirvožemio agrocheminès savybès (vidutiniai 2013 ir $2014 \mathrm{~m}$. duomenys): $\mathrm{pH}$ 6,67, humuso - 1,93\%, judriuju maisto medžiagų dirvožemyje: $\mathrm{P}_{2} \mathrm{O}_{5}-259 \mathrm{mg} \mathrm{kg}^{-1}$ ir $\mathrm{K}_{2} \mathrm{O}-140 \mathrm{mg} \mathrm{kg}^{-1}$. Eksperimento variantai: necheminiai piktžolių kontrolès būdai: 1) terminis (drègnuoju vandens garu); 2) mechaninis (tarpueiliu 
purenimas); 3) savireguliacija (stelbimas). Sèta linijinè vasarinių rapsų veislè 'Fenja' (Vokietija, WvB), $8 \mathrm{~kg} \mathrm{ha}^{-1}$, sejjamąja MULTIDRILL M 300. $2013 \mathrm{~m}$. vasariniai rapsai sèti balandžio 30 d., $2014 \mathrm{~m}$. - balandžio $22 \mathrm{~d}$. Taikant termini ir mechanini piktžolių kontrolès būdą rapsai auginti $48 \mathrm{~cm}$ tarpueiliais. Taikant termini kontrolès būdą piktžolès naikintos mobiliuoju piktžolių terminio naikinimo drègnuoju vandens garu įrenginiu (šiluminis galingumas - $90 \mathrm{~kW}$, našumas - $120 \mathrm{~kg} \mathrm{~h}^{-1}$ garo, kūrenamas suskystintomis dujomis). Garo temperatūra $-99^{\circ} \mathrm{C}$, terminio poveikio trukmè $-2 \mathrm{~s}$ (Sirvydas, Kerpauskas, 2012). Taikant mechanini piktžolių kontrolès būdą tarpueiliai purenti purentuvu (KOR-4.2-01, Ukraina), važiuojant du kartus. Taikant stelbimą rapsai auginti 12,0 cm tarpueiliais. Vasariniai rapsai netręšti, cheminès augalų apsaugos priemonès nenaudotos.

Pradinio laukelio plotas - $84 \mathrm{~m}^{2}$, apskaitinio $-20 \mathrm{~m}^{2}$. Tyrimai atlikti 4 pakartojimais. Priešsèlis - juodasis pūdymas. Eksperimento laukeliai išdèstyti sisteminiu būdu.

Dirvožemio agrocheminès savybès nustatytos prieš vasarinių rapsų sẻją. Tyrimams atlikti kiekviename eksperimento laukelyje dirvožemio grąžtu paimami èminiai iš $0-25 \mathrm{~cm}$ dirvožemio sluoksnio. Dirvožemio $\mathrm{pH}$ nustatytas potenciometriškai $1 \mathrm{n} \mathrm{KCl}$ ištraukoje, judrusis fosforas $\mathrm{P}_{2} \mathrm{O}_{5}$ ir judrusis kalis $\mathrm{K}_{2} \mathrm{O}$ ( $\mathrm{mg} \mathrm{kg}^{-1}$ dirvožemio) - Egnerio-RimoDomingo (A-L) metodu, organinè anglis - Heraeus aparatu, deginant méginius $900{ }^{\circ} \mathrm{C}$ temperatūroje. Humuso kiekis apskaičiuotas organinès anglies kieki padauginus iš koeficiento 1,724. Tyrimai atlikti Lietuvos agrarinių ir mišku mokslo centro (LAMMC) Agrocheminių tyrimų laboratorijoje. Dirvožemio vienetas eksperimente nustatytas pagal naujają Lietuvos dirvožemių klasifikaciją (LTDK-99), suderintą su FAO UNESCO Pasaulio dirvožemių žemèlapio legenda (Lietuvos dirvožemiai, 2001).

Vasarinių rapsų pasèlio tankumas (vnt. $\mathrm{m}^{-2}$ ) ivertintas skaičiuojant augalus kiekviename laukelyje keturiuose $0,25 \mathrm{~m}^{2}$ apskaitos ploteliuose.

Piktžolių daigų analizè atlikta prieš taikant terminị ir mechaninị piktžolių kontrolès būdą rapsų 3-4 lapelių tarpsniu (BBCH 13-14). Kiekviename laukelyje atsitiktinai pasirinktuose keturiuose $0,10 \mathrm{~m}^{2}$ apskaitos ploteliuose nustatytas piktžolių daigų skaičius bei rūšinè sudètis. Antrą kartą ši analizè atlikta pažymètuose apskaitos laukeliuose praejus 5-7 dienoms, kai piktžolių kontrolès bū- dai buvo panaudoti. Skirtingų piktžolių kontrolès būdų efektyvumas (E) piktžolių daigų pokyčiui (sunaikintas piktžolių daigų procentas nuo pradinio kiekio) apskaičiuotas pagal formulę:

$E=\left(S_{1}-S_{2}\right) / S_{1}^{*} 100 \%$;

$S_{1}$ - piktžolių daigų skaičius $1 \mathrm{~m}^{2}$ prieš naudojant kontrolès būdus,

$S_{2}$ - piktžolių daigų skaičius $1 \mathrm{~m}^{2}$ panaudojus kontrolès būdus.

Prieš nuimant vasarinių rapsų derlių (BBCH 79) kiekviename laukelyje keturiuose $0,25 \mathrm{~m}^{2}$ apskaitos ploteliuose nustatytas piktžolių skaičius, botaninè sudètis, piktžolès išdžiovintos džiovinimo spintoje $45^{\circ} \mathrm{C}$ temperatūroje ir pasvertos. Gautas piktžoliu skaičius perskaičiuotas vnt. $\mathrm{m}^{-2}$, o piktžolių sausųjų medžiagų masé $-\mathrm{g} \mathrm{m}^{-2}$ (Stancevičius, 1979).

Skirtumų tarp vidurkių esmingumas ịvertintas naudojant $t$ kriterijų, požymių tarpusavio ryšiai - koreliacija ir regresijos metodais. Tyrimu duomenų statistinè analizè atlikta naudojantis kompiuterine programa STAT iš programų paketo SELEKCIJA (Tarakanovas, Raudonius 2003). Piktžolètumo tyrimo duomenys, neatitinkantys normaliojo skirstinio dèsnio, prieš statistinį vertinimą buvo transformuoti $y=\ln x$ (Tarakanovas, 2002).

Meteorologinès sąlygos. $2013 \mathrm{~m}$. pavasaris buvo šaltas ir vèlyvas. Augalų vegetacija atsinaujino tik balandžio mèn. antrąji dešimtadienị. Gegužès mèn. buvo $3,8^{\circ} \mathrm{C}$ šiltesnis nei ịprasta, kritulių suma 10,0 mm viršijo daugiametę kritulių sumą. Ménesio HTK - 1,3 (optimalus drékinimas). Birželio mén. temperatūra $2,9{ }^{\circ} \mathrm{C}$ viršijo daugiametę temperatūrą, o kritulių iškrito $16,7 \mathrm{~mm}$ mažiau nei itprasta. Mènesio HTK - 0,83 (nepakankamai drègna). Liepos mèn. buvo šiltas ir drègnas. Vidutinè mènesio temperatūra $1,0^{\circ} \mathrm{C}$ viršijo daugiametę temperatūrą, o kritulių iškrito $37,3 \mathrm{~mm}$ daugiau nei iprasta. Mènesio HTK - 2,05 (drègmès perteklius). Piktžolèms plisti sąlygos buvo palankios. Vasarinių rapsų vegetacijos metu (nuo rapsų sudygimo iki derliaus nuemimo) aktyviujų temperatūrų $\left(\geq 10^{\circ} \mathrm{C}\right)$ suma sudarè $1803,4^{\circ} \mathrm{C}$, iškrito $287,9 \mathrm{~mm}$ kritulių, hidroterminis koeficientas $-1,60$.

$2014 \mathrm{~m}$. pavasaris buvo sausas ir šiltas. Balandžio mèn. vidutinè temperatūra $3,0{ }^{\circ} \mathrm{C}$ viršijo daugiametę, o kritulių iškrito $17,1 \mathrm{~mm}$ mažiau nei iprasta. Mènesio HTK - 1,19 (optimalus drèkinimas). Gegužès mèn. buvo $0,9{ }^{\circ} \mathrm{C}$ šiltesnis nei iprasta, kritulių suma $30,4 \mathrm{~mm}$ viršijo daugiametę 
kritulių sumą. Mėnesio HTK - 2,36 (drègmès perteklius). Birželio mèn. buvo šaltas ir sausas. Mènesio HTK - 1,16 (optimalus drèkinimas). Liepos mèn. temperatūra $2,9{ }^{\circ} \mathrm{C}$ viršijo daugiametę, $\mathrm{o}$ kritulių iškrito $28,7 \mathrm{~mm}$ mažiau nei ịprasta. Mènesio HTK - 0,80 (menka sausra). Piktžolèms plisti sąlygos buvo mažiau palankios. Vasarinių rapsų vegetacijos metu aktyviųjų temperatūrų suma sudarè $1831,1^{\circ} \mathrm{C}$, iškrito $260,4 \mathrm{~mm}$ kritulių, hidroterminis koeficientas $-1,72$.

\section{TYRIMŲ REZULTATAI IR JŲ APTARIMAS}

Abejais tyrimų metais (2013 ir 2014) vasarinių rapsų pasèlyje vyravo trumpaamžès dviskiltès piktžolių rūšys: baltoji balanda (Chenopodium album L.), raudonžiedè notrelè (Lamium purpureum L.) ir daržinè žliūgè (Stellaria media (L.) Vill) (1 lentelè). $2013 \mathrm{~m}$. rapsų pasèlyje plito ir dirvinè veronika (Veronica arvensis L.). Iš daugiamečių piktžolių vasarinių rapsų pasėlyje rasta dirvinè pienė (Sonchus

1 lentelè. Vasarinių rapsų pasėlyje vyravusios piktžolių rūšys, 2013 ir 2014 m.

Table 1. Dominant weeds in spring oilseed rape crop, 2013 and 2014

\begin{tabular}{|c|c|c|c|c|}
\hline \multirow{3}{*}{$\begin{array}{l}\text { Piktžolių rūšys } \\
\text { Weed species }\end{array}$} & \multirow{3}{*}{$\begin{array}{l}\text { Piktžolių kontrolès būdų } \\
\text { panaudojimas } \\
\text { Application of weed control } \\
\text { methods }\end{array}$} & \multicolumn{3}{|c|}{$\begin{array}{l}\text { Piktžolių kontrolès būdai } \\
\text { Weed control methods }\end{array}$} \\
\hline & & 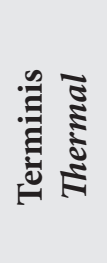 & 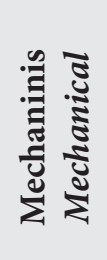 & 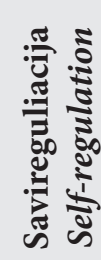 \\
\hline & & \multicolumn{3}{|c|}{$\begin{array}{l}\text { Skaičius vnt. } \mathrm{m}^{-2} \\
\text { Number, units } \mathrm{m}^{-2}\end{array}$} \\
\hline \multicolumn{5}{|c|}{$2013 \mathrm{~m}}$. \\
\hline \multirow{2}{*}{$\begin{array}{c}\text { Baltoji balanda } \\
\text { Chenopodium album L. }\end{array}$} & Prieš naudojimą / Before application & 51,6 & 25,6 & 46,6 \\
\hline & Po naudojimo / After application & 39,4 & 20,0 & 47,8 \\
\hline \multirow{2}{*}{$\begin{array}{l}\text { Dirvinè veronika } \\
\text { Veronica arvensis L. }\end{array}$} & Prieš naudojimą / Before application & 28,8 & 25,3 & 21,9 \\
\hline & Po naudojimo / After application & 16,6 & 8,12 & 29,4 \\
\hline \multirow{2}{*}{$\begin{array}{l}\text { Raudonžiedė notrelè } \\
\text { Lamium purpureum L. }\end{array}$} & Prieš naudojimą / Before application & 25,1 & 6,90 & 20,0 \\
\hline & Po naudojimo / After application & 16,6 & 8,74 & 25,0 \\
\hline \multirow{2}{*}{$\begin{array}{c}\text { Daržinè žliūgè } \\
\text { Stellaria media (L.) Vill. }\end{array}$} & Prieš naudojimą / Before application & 11,8 & 10,6 & 7,82 \\
\hline & Po naudojimo / After application & 8,44 & 10,6 & 8,12 \\
\hline \multirow{2}{*}{$\begin{array}{c}\text { Trumpamakštis rūgtis } \\
\text { Persicaria lapathifolia (L.) Gray }\end{array}$} & Prieš naudojimą / Before application & 17,2 & 4,06 & 6,25 \\
\hline & Po naudojimo / After application & 10,6 & 2,81 & 6,56 \\
\hline \multirow{2}{*}{ Kitos / Other } & Prieš naudojimą / Before application & 30,9 & 31,3 & 53,1 \\
\hline & Po naudojimo / After application & 25,6 & 20,6 & 57,9 \\
\hline \multicolumn{5}{|c|}{$2014 \mathrm{~m}$} \\
\hline \multirow{2}{*}{$\begin{array}{c}\text { Baltoji balanda } \\
\text { Chenopodium album L. }\end{array}$} & Prieš naudojimą / Before application & 96,8 & 53,1 & 63,1 \\
\hline & Po naudojimo / After application & 48,8 & 11,2 & 55,0 \\
\hline \multirow{2}{*}{$\begin{array}{l}\text { Raudonžiedè notrelè } \\
\text { Lamium purpureum L. }\end{array}$} & Prieš naudojimą / Before application & 11,9 & 18,1 & 11,2 \\
\hline & Po naudojimo / After application & 8,12 & 6,25 & 10,6 \\
\hline \multirow{2}{*}{$\begin{array}{l}\text { Dirvinis garstukas } \\
\text { Sinapis arvensis L. }\end{array}$} & Prieš naudojimą / Before application & 7,50 & 6,25 & 6,88 \\
\hline & Po naudojimo / After application & 4,38 & 1,88 & 11,2 \\
\hline \multirow{2}{*}{$\begin{array}{c}\text { Daržinè žliūgè } \\
\text { Stellaria media (L.) Vill. }\end{array}$} & Prieš naudojimą / Before application & 5,62 & 4,38 & 6,88 \\
\hline & Po naudojimo / After application & 3,12 & 1,88 & 11,2 \\
\hline \multirow{2}{*}{$\begin{array}{c}\text { Bekvapis šunramunis } \\
\text { Tripleurospermum perforatum } \\
\text { (Merat) M. Lainz }\end{array}$} & Prieš naudojimą / Before application & 5,62 & 0,62 & 3,12 \\
\hline & Po naudojimo / After application & 3,12 & 0 & 5,00 \\
\hline \multirow{2}{*}{ Kitos / Other } & Prieš naudojimą / Before application & 19,5 & 16,8 & 25,2 \\
\hline & Po naudojimo / After application & 20,6 & 3,12 & 74,4 \\
\hline
\end{tabular}


arvensis L.), dirvinè usnis (Cirsium arvense (L.) Scop), dirvinis asiūklis (Equisetum arvense L.). V. Danhel ir kt. (2014) duomenimis, rapsu pasèliuose taip pat daugiausia plinta trumpaamžès dviskiltės piktžolių rūšys: veronika (Veronica spp.), daržinè žliūgè, bekvapis šunramunis (Tripleurospermum perforatum (Merat) M. Lainz), dirvinè čiužute (Thlapsi arvense L.), trikertè žvaginè (Capsella bursa-pastoris L. Medik), raudonžiedè notrelè ir kt.

Abejais tyrimų metais tiriamuose laukeliuose susiformavo skirtingas vasarinių rapsų pasèlio tankumas (2 lentelè). Mažiausias rapsų pasèlio tankumas susidare juos auginant siaurais $(12 \mathrm{~cm})$ tarpueiliais (savireguliacijos laukeliuose). Eilutèse esant mažesniam augalų skaičiui, didejja rapsų ir piktžolių konkurencija. 2013 m. taikant stelbimą, palyginti su terminiu ir mechaniniu piktžolių kontrolès būdais, augalų skaičius ploto vienete esmingai mažejjo nuo 2,2 iki 2,4 karto, o 2014 m. - nuo 1,5 iki 1,9 karto.

Prieš panaudojant piktžolių kontrolès būdus 2013 ir 2014 m. visuose tiriamuose rapsų laukeliuose piktžolių daigų rasta panašiai (2 lentelè). Piktžolių daigų skaičius vasarinių rapsų pasèlyje kito nuo 102,8 iki 163,8 vnt. $\mathrm{m}^{-2} 2013 \mathrm{~m}$. ir nuo 99,0 iki 146,0 vnt. $\mathrm{m}^{-2} 2014 \mathrm{~m}$. Abejais tyrimų metais dau- giausia rasta baltosios balandos daigų, atitinkamai nuo 25,6 iki 96,8 vnt. $\mathrm{m}^{-2}$ (1 lentelè).

Po piktžolių kontrolès būdų taikymo abejais tyrimų metais daugiausia piktžolių daigų išliko savireguliacijos laukeliuose (2 lentelè). Piktžolių daigu skaičius esmingai mažèjo taikant rapsų pasèlyje termini (nuo 1,5 iki 1,8 karto) ir mechanini (nuo 2,5 iki 6,8 karto) piktžolių kontrolès būdus, palyginti su savireguliacija. Mechaninès piktžolių kontrolès laukeliuose piktžolių daigų nustatyta esmingai nuo 1,6 iki 3,7 karto mažiau, palyginti su terminès piktžolių kontrolès drègnuoju vandens garu laukeliais.

İvertinus skirtingų piktžolių kontrolès būdų efektyvumą piktžolių daigu pokyčiui rapsu pasèlyje 2013 m., mechaninio bei terminio piktžolių kontrolès būdų efektyvumas buvo panašus, atitinkamai 28,4 ir $30,9 \%$, o 2014 m. mechaninio piktžoliu naikinimo efektyvumas - 1,9 karto didesnis nei terminio (1 pav.).

Taikant tiek termini, tiek ir mechanini piktžoliu kontrolès būdą baltosios balandos daigų $2013 \mathrm{~m}$. sumažèjo panašiai - atitinkamai 23,6 ir 21,9 \% (1 lentelè). 2014 m. mechaninio piktžolių kontrolès būdo efektyvumas (78,9 \%) baltajai balandai buvo 1,6 karto didesnis negu terminio (49,6\%). Terminès piktžolių kontrolès efektyvumas raudonžiedès

2 lentelè. Vasarinių rapsų pasèlio tankumas ir piktžolètumas pavasarị, 2013 ir 2014 m.

Table 2. Spring oilseed rape crop density and weediness in spring, 2013 and 2014

\begin{tabular}{|c|c|c|c|c|c|c|}
\hline \multirow[b]{3}{*}{$\begin{array}{l}\text { Piktžolių } \\
\text { kontrolès } \\
\text { būdai } \\
\text { Weed control } \\
\text { methods }\end{array}$} & \multicolumn{6}{|c|}{ Metai / Years } \\
\hline & \multicolumn{3}{|c|}{2013} & \multicolumn{3}{|c|}{2014} \\
\hline & $\begin{array}{c}\text { Rapsu } \\
\text { pasèlio } \\
\text { tankumas } \\
\text { vnt. } \mathbf{m}^{-2} \\
\text { Oilseed } \\
\text { rape crop } \\
\text { density, } \\
\text { plants } \mathbf{m}^{-2}\end{array}$ & $\begin{array}{c}\text { Piktžolių } \\
\text { daigų sk. prieš } \\
\text { panaudojant } \\
\text { kontrolès } \\
\text { būdus } \\
\text { vnt. m }{ }^{-2} \\
\text { Number of } \\
\text { weed seedlings } \\
\text { before applica- } \\
\text { tion of weed } \\
\text { control } \\
\text { methods, } \\
\text { units } \text { m }^{-2}\end{array}$ & $\begin{array}{l}\text { Piktžolių } \\
\text { daigų sk. } \\
\text { panaudojus } \\
\text { kontrolès } \\
\text { būdus } \\
\text { vnt. } \text { m }^{-2} \\
\text { Number of } \\
\text { weed seed- } \\
\text { lings after } \\
\text { application of } \\
\text { weed control } \\
\text { methods, } \\
\text { units } \text { m }^{-2}\end{array}$ & $\begin{array}{c}\text { Rapsu } \\
\text { pasėlio } \\
\text { tanku- } \\
\text { mas } \\
\text { vnt. m }{ }^{-2} \\
\text { Oilseed } \\
\text { rape } \\
\text { crop } \\
\text { density, } \\
\text { plants } \\
m^{-2}\end{array}$ & $\begin{array}{c}\text { Piktžolių } \\
\text { daigų sk. prieš } \\
\text { panaudojant } \\
\text { kontrolès } \\
\text { būdus } \\
\text { vnt. } \text { m }^{-2} \\
\text { Number of } \\
\text { weed seedlings } \\
\text { before ap- } \\
\text { plication of } \\
\text { weed control } \\
\text { methods, } \\
\text { units } \text { m }^{-2}\end{array}$ & $\begin{array}{l}\text { Piktžolių } \\
\text { daigų sk. } \\
\text { panaudojus } \\
\text { kontrolès } \\
\text { būdus } \\
\text { vnt. m }{ }^{-2} \\
\text { Number of } \\
\text { weed seedlings } \\
\text { after applica- } \\
\text { tion of weed } \\
\text { control } \\
\text { methods, } \\
\text { units } \text { m }^{-2}\end{array}$ \\
\hline $\begin{array}{l}\text { Terminis } \\
\text { Thermal }\end{array}$ & $139,0 \mathrm{a}$ & $163,8 \mathrm{a}$ & $117,2 b$ & $185,0 \mathrm{a}$ & $146,0 \mathrm{a}$ & $88,0 \mathrm{~b}$ \\
\hline $\begin{array}{l}\text { Mechaninis } \\
\text { Mechanical }\end{array}$ & $130,0 \mathrm{a}$ & $102,8 b$ & $71,0 \mathrm{c}$ & $230,0 a$ & $99,0 \mathrm{a}$ & $24,0 \mathrm{c}$ \\
\hline $\begin{array}{l}\text { Savireguliacija } \\
\text { Self-regulation }\end{array}$ & $58,0 \mathrm{~b}$ & $155,6 a$ & $174,7 \mathrm{a}$ & $121,0 \mathrm{~b}$ & $112,0 \mathrm{a}$ & $162,0 \mathrm{a}$ \\
\hline
\end{tabular}

Pastaba / Note: tarp variantų vidurkių, pažymètų ne ta pačia raide (a, b), skirtumai yra esminiai $(P<0,05) /$ Means not sharing a common letter $(a, b)$ are significantly different $(P<0.05)$. 


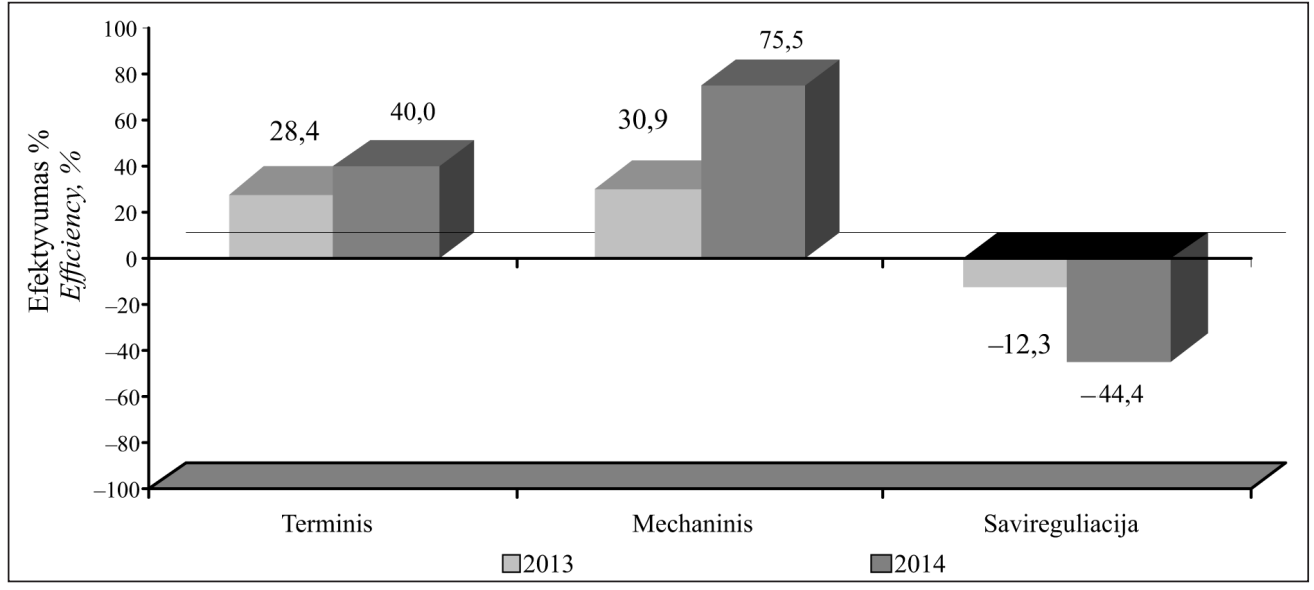

1 pav. Skirtingų piktžolių kontrolès būdų efektyvumas piktžolių daigų skaičiui vasarinių rapsų pasèlyje, 2013 ir $2014 \mathrm{~m}$.

Fig. 1. The efficiency of different weed control methods on weed seedlings in spring oilseed rape crop, 2013 and 2014

notrelès daigų pokyčiui vasarinių rapsų pasèlyje abejais tyrimo metais išliko stabilus, atitinkamai 33,9 ir $31,8 \%$, o mechaninès piktžolių kontrolès efektyvumas buvo skirtingas ir priklausè nuo metų meteorologinių sąlygų. Esant šiltam ir sausam $2014 \mathrm{~m}$. pavasariui raudonžiedès notrelès daigų mechaniniu būdu buvo sunaikina 65,5\%. $2013 \mathrm{~m}$. taikant terminị piktžolių kontrolès būdą dirvinès veronikos daigų sunaikinta $42,4 \%$, o taikant mechanini - 67,9\%.

Abejais tyrimų metais savireguliacijos (stelbimo) efektyvumas piktžolėms buvo neigiamas - piktžolių daugèjo 12,3-44,4 \% nuo pradinio kiekio. R. Virbickaitè ir kt. (2006) nustatè, kad terminès piktžolių kontrolès drègnuoju vandens garu efektyvumas trumpaamžèms piktžolèms siekė 22,5\%. J. Lieven ir kt. (2008) duomenimis, rapsus auginant plačiais tarpueiliais ir juos purenant (vieną arba du kartus), dirvinis garstukas, našlaitès (Viola spp.), notrelès (Lamium spp.) visai sunyko, o pienių (Sonchus spp.) sumažejo nuo 3,6 iki 4,0 karto.

Prieš nuimant vasarinių rapsų derlių pasèlyje vyravo baltoji balanda, dirvinis garstukas ir trumpamakštis rūgtis. Ivertinus piktžolių skaičių nustatytos panašios tendencijos abejais tyrimų metais. Didžiausias piktžolių skaičius rastas savireguliacijos laukeliuose (nuo 59,2 iki 80,0 vnt. $\mathrm{m}^{-2}$ ) (2 pav.). Taikant termini bei mechanini piktžolių kontrolès būdą, palyginti su savireguliacija, 2013 m. piktžolių

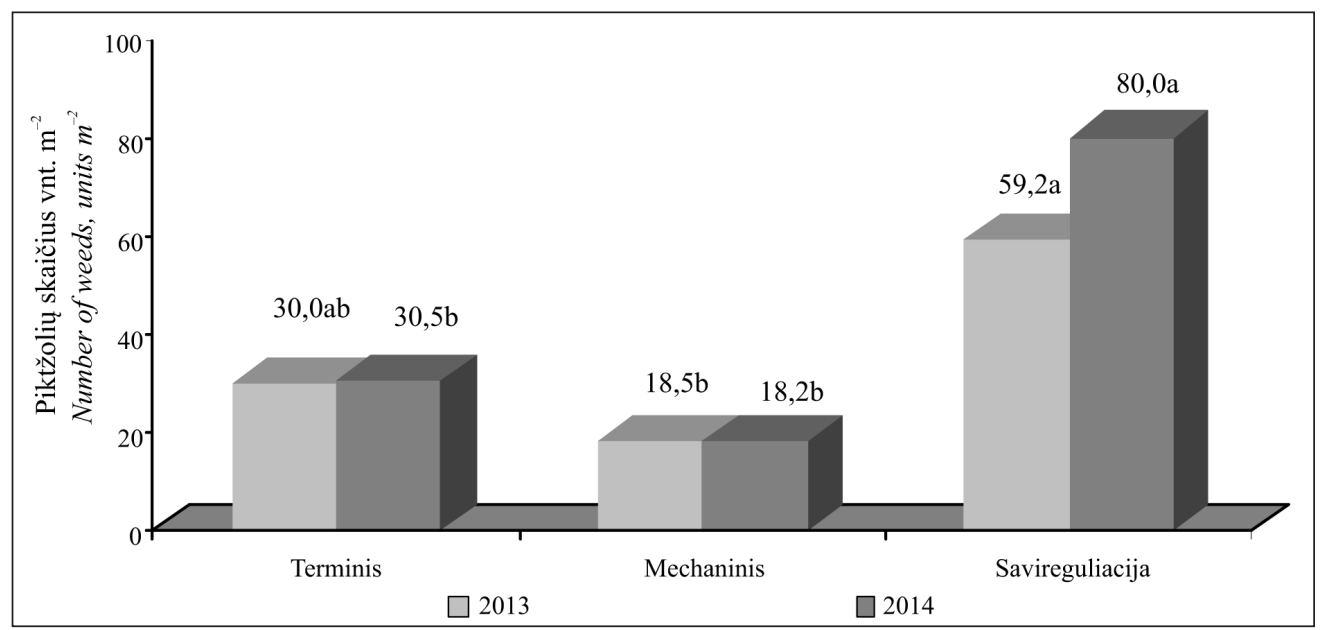

2 pav. Piktžolių skaičius vasarinių rapsų pasèlyje prieš nuimant derlių, 2013 ir 2014 m. (tarp variantų vidurkių, pažymėtų ne ta pačia raide $(\mathrm{a}, \mathrm{b})$, skirtumai yra esminiai $(\mathrm{P}<0,05))$

Fig. 2. The number of weeds in spring oilseed rape crop before harvesting, 2013 and 2014 (means not sharing a common letter $(a, b)$ are significantly different $(P<0.05)$ ) 
skaičius esmingai mažèjo nuo 2,0 iki 3,2 karto, o 2014 m. - nuo 2,6 iki 4,4 karto. Terminès bei mechaninès piktžolių kontrolès laukeliuose piktžolių skaičius esmingai nesiskyrè.

Tyrimai parodè, kad $2013 \mathrm{~m}$. didžiausia piktžolių sausųjų medžiagų mase $\left(165,2 \mathrm{~g} \mathrm{~m}^{-2}\right)$ buvo stelbimo laukeliuose ( 3 pav.). Taikant termini (2,3 karto) bei mechaninị (3,1 karto) piktžolių kontrolès būdą rapsų pasèlyje esmingai mažèjo piktžolių sausųjų medžiagų masè, palyginti su savireguliacijos taikymu. Terminès bei mechaninès piktžolių kontrolès laukeliuose piktžolių sausųjų medžiagų masè esmingai nesiskyrè. $2014 \mathrm{~m}$. didžiausia piktžolių sausųu medžiagų masè $\left(185,7 \mathrm{~g} \mathrm{~m}^{-2}\right)$ buvo terminès piktžo- lių kontrolès laukeliuose, kuriuose nustatytas ir didžiausias piktžolių daigu skaičius prieš panaudojant kontrolès būdus. Taikant mechanini piktžolių kontrolès būdą, palyginti su terminiu, piktžolių sausujų medžiagu masè rapsų pasèlyje esmingai 4,3 karto mažèjo. Savireguliacijos laukeliuose, palyginti su mechaniniu piktžolių kontrolès būdu, piktžolių sausụjų medžiagų masė didèjo, tačiau esminių skirtumų nenustatyta. Dèl mažesnès tarprūšinès konkurencijos susiformavę vešlesni ir tolygiai pasiskirstę rapsai taip pat gerai stelbẻ piktžoles.

Savireguliacijos laukeliuose abejais tyrimų metais vasarinių rapsų sèklų derlingumas buvo panašus (4 pav.). Didejjant terminio bei mechaninio piktžoliu

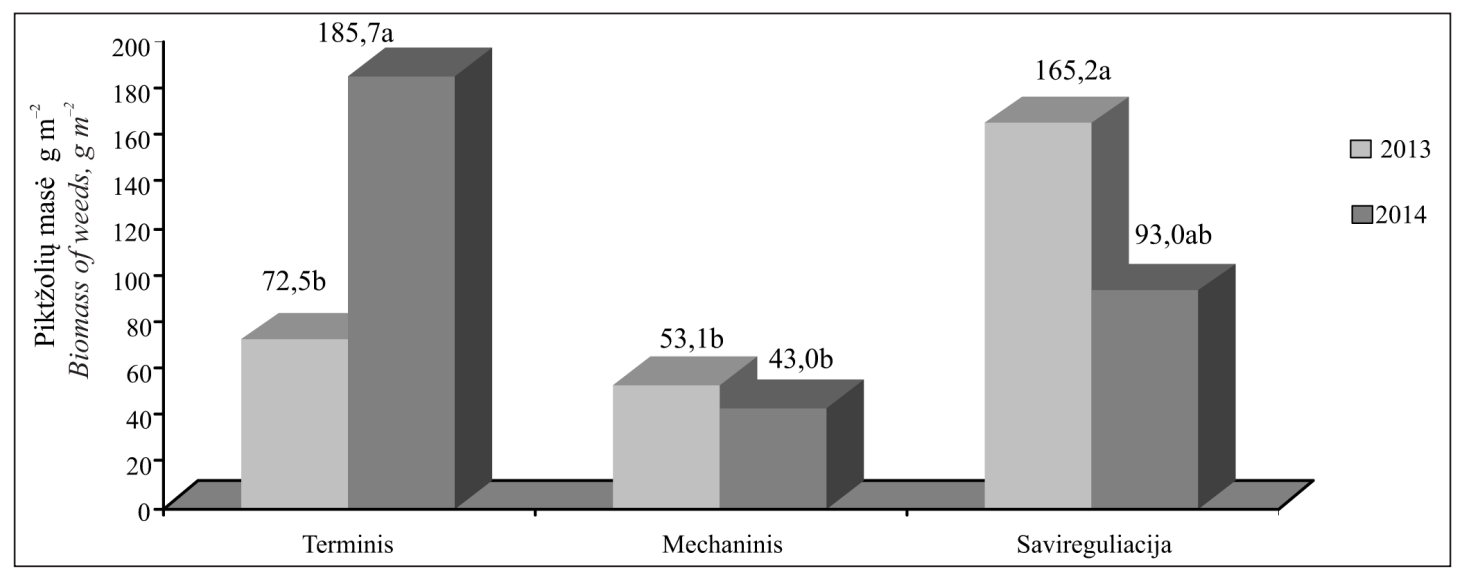

3 pav. Piktžolių sausujų medžiagų masė vasarinių rapsų pasėlyje prieš nuimant derlių, 2013 ir $2014 \mathrm{~m}$. (tarp variantų vidurkių, pažymètų ne ta pačia raide $(\mathrm{a}, \mathrm{b})$, skirtumai yra esminiai $(P<0,05))$

Fig. 3. Dry biomass of weeds in spring oilseed rape crop before harvesting, 2013 and 2014 (means not sharing a common letter $(a, b)$ are significantly different $(P<0.05))$

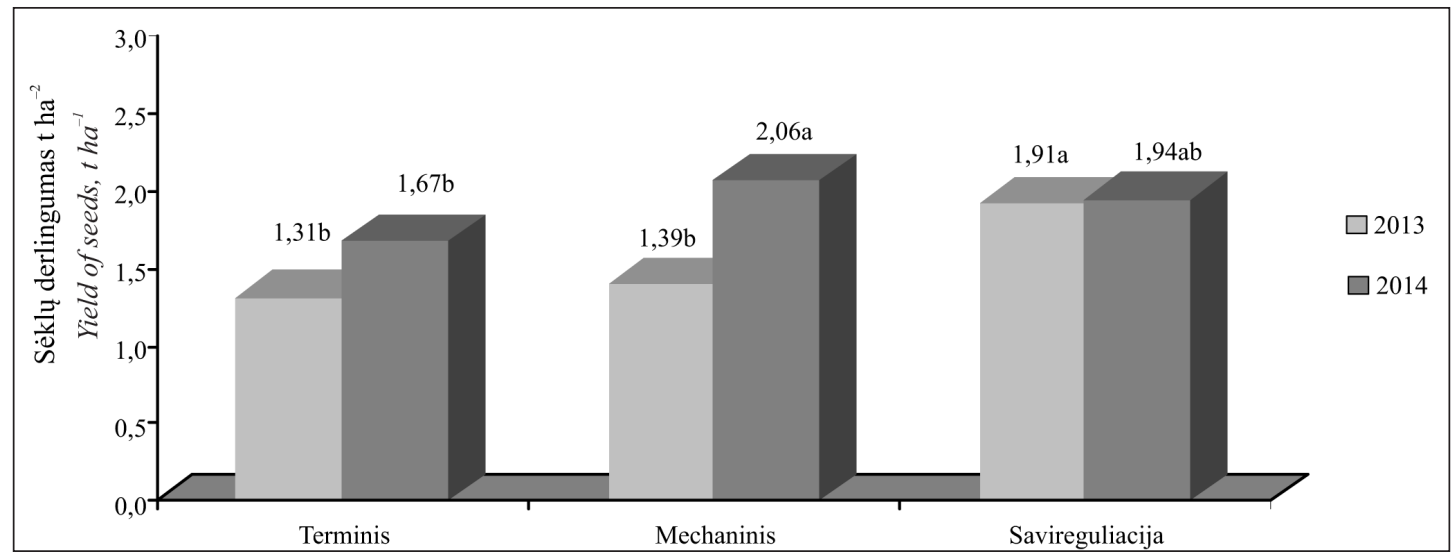

4 pav. Vasarinių rapsų sẻklų derlingumas naudojant skirtingus necheminius piktžolių kontrolès būdus, 2013 ir 2014 m. (tarp variantų vidurkių, pažymètų ne ta pačia raide (a, b), skirtumai yra esminiai $(\mathrm{P}<0,05))$

Fig. 2. The yield of spring oilseed rape seeds after application of different non-chemical weed control methods, 2013 and 2014 (means not sharing a common letter $(a, b)$ are significantly different $(P<0.05)$ ) 
kontrolès būdų efektyvumui, didèjo ir vasarinių rapsų sèklų derlingumas. $2013 \mathrm{~m}$. terminès bei mechaninès piktžolių kontrolès laukeliuose rapsų sèklų derlingumas esmingai nesiskyrè, o $2014 \mathrm{~m}$. efektyvesnis buvo mechaninis piktžolių kontrolès būdas - rapsų sèklų derlingumas esmingai $23,4 \%$ didejo.

2014 m. tarp vasarinių rapsų sẻklų derlingumo ir piktžolių daigų skaičiaus prieš panaudojant kontrolès priemones $(y=2,87-0,008 x, r=-0,99$, $r<0,05)$ bei tarp rapsų sèklų derlingumo ir piktžolių sausųjų medžiagų masès prieš nuimant derlių $(y=2,19-0,003 x, r=-0,99, r<0,05)$ nustatyti neigiami, labai stiprūs ir statistiškai patikimi koreliaciniai priklausomumai. Tai įrodo, kad piktžolių naikinimas ekologiškai auginamų vasarinių rapsų pasèlyje yra svarbus.

\section{IŠVADOS}

1. Pavasarį vasarinių rapsų pasèlyje vyravo baltoji balanda, raudonžiedè notrelè ir daržinè žliūgè. Mechaniniam piktžolių naikinimui jautriausia buvo baltoji balanda, o terminiam - raudonžiedè notrelè ir daržinè žliūgè.

2. Piktžolių daigų skaičius esmingai mažèjo taikant termini (nuo 1,5 iki 1,8 karto) bei mechanini (nuo 2,5 iki 6,8 karto) piktžolių kontrolès būdą vasarinių rapsų pasėlyje, palyginti su savireguliacija.

3. Efektyviausias piktžolių kontrolès būdas ekologiškai auginamų rapsų pasèlyje buvo mechaninis (efektyvumas 30,9-75,5 \%). Terminio piktžoliu kontrolès būdo efektyvumas, palyginti su mechaniniu, buvo mažesnis $(28,4-40,0 \%)$.

4. Prieš nuimant derlių rapsų pasèlyje, kur buvo taikytas mechaninis piktžolių naikinimas, palyginti su savireguliacija, piktžolių skaičius buvo esmingai mažesnis 3,2-4,4 karto, piktžolių sausưjų medžiagų masè - 2,2-3,1 karto.

5. Auginant vasarinius rapsus ekologinès gamybos ūkiuose efektyviau taikyti mechaninị piktžolių kontrolès būdą negu terminị, nes vidutinis rapsų sèklų derlingumas gaunamas 15,8 \% didesnis.

6. Vasarinių rapsų derlingumas priklausè nuo piktžolių daigų skaičiaus prieš panaudojant kontrolès būdus $(r=-0,99, r<0,05)$ ir piktžolių sausujų medžiagų masès prieš nuimant derlių $(r=-0,99$, $r<0,05)$.

Gauta 20150930 Priimta 20151207

\section{LITERATŪRA}

1. Auškalnienè O., Lukošiūnas K. 2003. Akèjimo poveikis piktžolems ir vasarinių miežiu derliui. Žemès ùkio inžinerija: LŽŪII ir LŽŪU mokslo darbai. T. 35. Nr. 2. P. 15-26.

2. Börner H. 1995. Unkrautbekämpfung. Stuttgart. $315 \mathrm{p}$.

3. Bullied W. J., Van Acker R. C., Marginet A. M., Kenkel N. C. 2006. Agronomic and environmental factors influence weed composition and canola competitiveness in southern Manitoba. Canadian Journal of Plant Science. Vol. 86. No. 2. P. 591-599.

4. Collins R. M. 2000. Australian Developments in Thermal Weed Control. Proceedings of 4th EWRS Workshop on Physical Weed Control. Elspeet, The Netherlands. P. 56-58.

5. Danhel V., Chovancova S., Winkler J. 2014. Weed species spectrum of chosen field crops. MendelNet. P. 23-27.

6. Debeljak M., Squire G. R., Demšar D., Young M. W., Džeroski S. 2008. Relations between the oilseed rape volunteer seedbank, and soil factors, weed functional groups and geographical location in the UK. Ecological Modelling. Vol. 212. No. 1-2. P. 138-146.

7. Hamzei J., Nasab A. D. M., Khoie F. R., Javanshir A. 2007. Critical period of weed control in three winter oilseed rape cultivars. Turkish Journal of Agriculture and Forestry. Vol. 31. P. 83-90.

8. Kerpauskas P. 2003. Lokalizuotos aplinkos terminiam piktžoliu naikinimui formavimas ir tyrimas: daktaro disertacija. Akademija, Kauno r. 113 p.

9. Kerpauskas P., Čekanauskas S., Ūksas T. 2010. Temperatūros kitimas dirvos paviršiuje piktžolių terminio naikinimo procese. Šilumos energetika ir technologijos: konferencijos pranešimų medžiaga. Kauno technologijos universitetas. P. 249-254.

10. Kerpauskas P., Sirvydas A. P., Lazauskas P., Vasinauskienè R., Tamošiūnas A. 2006. Possibilities of weed control by water steam. Agronomy Research. Vol. 4. P. 221-225.

11. Kurstjens D. A. G., Kropff M. J. 2001. The impact of uprooting and soil covering on the effectiveness of weed harrowing. Weed Research. Vol. 41. No. 3. P. 211-228.

12. Kurstjens D. A. G., Perdok U. D. 2000. The selective soil covering mechanism of weed harrows on sandy soil. Soil Tillage Research. Vol. 55. No. 3-4. P. 193206.

13. Lazauskas P. 1990. Agrotechnika prieš piktžoles: monografija. Vilnius: Mokslas. 214 p.

14. Lieven J., Quere L., Lucas J. L. 2008. Oilseed rape weed integrated management: concern of mechanical weed control. Diversifying Crop Protection: Proceedings of ENDURE International Conference. La Grande-Motte, France. P. 1-4.

15. Lietuvos dirvožemiai: monografija. 2001. Vilnius: LMA. $1244 \mathrm{p}$. 
16. Lundkvist A., Salomonsson L., Karlsson L., Gustavsson A. M. D. 2008. Effects of organic farming on weed flora composition in a long term perspective. European Journal of Agronomy. Vol. 28. No. 4. P. 570-578.

17. Melander B., Munier-Jolain N., Charles R., Wirth J., Schwarz J., Van der Weide, Bonin L., Jensen P. K., Kudsk P. 2013. European perspectives on the adoption of nonchemical weed management in reducedtillage systems for arable crops. Weed Technology. Vol. 27. No. 1. P. 231-240.

18. Oerke E. C. 2005. Crop losses to pests. Journal of Agricultural Science. Vol. 144. No. 1. P. 31-43.

19. Pilipavičius V. 2006. Piktžolių išdygimo ir išlikimo dinamika vasarinių miežių pasèlyje. Vagos: mokslo darbai. LŽŪU. T. 72. Nr. 25. P. 47-52.

20. Praczyk T. 2005. Zwalczanie chwastów. Rozdział w: Technologia produkcji rzepaku. Wydawnictwo Wieś Jutra. Warszawa, in Polish. S. 97-107.

21. Seem J. E., Cramer N. G., Monks D. V. 2003. Critical weed-free period for 'Beauregard' sweet potato (Ipomoea batatas). Weed Technology. Vol. 17. No. 4. P. 686-695.

22. Sirvydas P. A., Kerpauskas P. 2012. Terminis piktžoliu naikinimas: monografija. Akademija, Kauno r. $327 \mathrm{p}$.

23. Stancevičius A. 1979. Piktžolių apskaita ir laukų piktžoletumo kartografavimas. Vilnius. 37 p.

24. Staniulienè R. 2010. Aukštatemperatūrinès aplinkos poveikis sunkiai termiškai sunaikinamoms piktžolems: daktaro disertacija. Akademija, Kauno r. $80 \mathrm{p}$.

25. Tarakanovas P. 2002. Biologinių bandymų duomenų transformavimas taikant kompiuterinę programą „Anova“. Žemdirbyste. T. 77. P. 170-180.

26. Tarakanovas P., Raudonius S. 2003. Agronominiu tyrimy statistine analizé taikant kompiuterines programas ANOVA iš paketo "Selekcija“ ir "Irristat“. Akademija, Kèdainių r. 57 p.

27. Valantin-Morison M., Meynard J. M. 2008. Diagnosis of limiting factors of organic oilseed rape yield. A survey of farmers' fields. Agronomy for Sustainable Development. Vol. 28. No. 4. P. 527-539.

28. Vasinauskienè R. 2004. Termines aplinkos poveikio augalams tyrimai ir agrotechnologinis ivertinimas: daktaro disertacija. Akademija, Kauno r. 99 p.

29. Velička R., Trečiokas K. 2002. Žieminių ir vasarinių rapsų ịtaka pasèlių piktžolètumui ịvairiose sẻjomainose. Vagos: mokslo darbai. LŽŪU. Vol. 53. No. 6. P. 31-40.

30. Virbickaitė R., Sirvydas P. A., Kerpauskas P., Vasinauskienè R. 2006. The comparison of thermal and mechanical systems of weed control. Agronomy Research. Vol. 4. P. 451-455.

31. Zakharenko A. V. 2000. Teoreticheskie osnovy upravleniua sornym komponentom agrofitotsenoza $v$ sistemakh zemledeliya. Moskva: MCXA. 466 s.
Rimantas Velička, Rita Mockevičienè, Aušra Marcinkevičienè, Rita Pupalienė, Lina Marija Butkevičienè, Zita Kriaučiūnienè, Robertas Kosteckas, Sigitas Čekanauskas

\section{THE COMPARISON OF NON-CHEMICAL WEED CONTROL METHODS EFFICIENCY IN SPRING OILSEED RAPE CROP UNDER THE CONDITIONS OF ORGANIC FARMING SYSTEM}

Sum mary

There is a considerable amount of investigations on oilseed rape cultivated in an organic system, but a lack of investigations in Lithuanian climate conditions, particularly with innovative weed control methods. Field experiments were conducted at the Experimental Station of Aleksandras Stulginskis University in 2013 and 2014 and the soil was (IDg4-k) Calc(ar)i-Endohypogleyic Luvisol (LVg-n-w-cc). This study aims to determine the impact of different non-chemical weed control methods on the spring oilseed rape (Brassica napus L.) crop weediness and yield of seeds under the conditions of the organic farming system. The following non-chemical weed control methods were used: 1) thermal (water steam), 2) mechanical (inter-row loosening), and 3) self-regulation (smothering). Chenopodium album, Lamium purpureum and Stellaria media dominated in spring oilseed rape crop in spring. Chenopodium album was the most responsive to the mechanical weed control method, and Lamium purpureum and Stellaria media were the most responsive to the thermal weed control method. It was estimated that thermal (from 1.5 to 1.8 times) and mechanical (from 2.5 to 6.8 times) weed control methods significantly $(\mathrm{P}<0.05)$ reduced the number of weed seedlings in spring oilseed rape crop, compared with the weed smothering system. The most effective method of weed control in organically grown rape crop was the mechanical control method (efficiency 30.9-75.5\%). The efficiency of the thermal weed control method, compared with that of the mechanical method, was lower $-28.4-40.0 \%$. Before rape harvesting in plots where the mechanical weed control was applied, compared with plots where weed smothering was used, the number of weeds was significantly $(\mathrm{P}<0.05)$ 3.2-4.4 times lower, and the dry matter biomass of weeds was 2.2-3.1 times lower. In the self-regulation plots the yield of spring oilseed rape seeds was similar in both years. In spring oilseed rape crops in the organic farming system the application of the mechanical weed control method is more effective than the application of the thermal weed control method as the seed yield of spring oilseed rape was established 15.8\% higher in the plots where the mechanical weed control method was used. The yield of spring oilseed rape seeds depended on the number of weed seedlings $(r=-0.99, r<0.05)$ and the dry biomass of weeds $(r=-0.99, r<0.05)$ before rape harvesting.

Key words: Brassica napus L. ssp. oleifera annua Metzg., weed control methods, weed, efficiency, yield of seeds, organic farming 